medRxiv preprint doi: https://doi.org/10.1101/2022.01.07.22268893; this version posted January 7, 2022. The copyright holder for this preprint (which was not certified by peer review) is the author/funder, who has granted medRxiv a license to display the preprint in perpetuity.

It is made available under a CC-BY-ND 4.0 International license .

\title{
Mobile Phone Virtual Reality Game for Pediatric Home Burn Dressing Pain Management, a Randomized Clinical Trial
}

Megan Armstrong, MPH ${ }^{1,2}$; Jonathan Lun, BS ${ }^{1,2,3}$; Jonathan I. Groner, MD ${ }^{1,2,4,5}$; Rajan K. Thakkar, $\mathrm{MD}^{1,4,5}$; Renata Fabia, MD, PhD ${ }^{1,4,5}$; Dana Noffsinger, CPNP-AC ${ }^{1,4}$; Henry Xiang, MD, MPH, PhD, $\mathrm{MBA}^{1,2,5}$

\author{
Affiliations: \\ ${ }^{1}$ Center for Pediatric Trauma Research, The Abigail Wexner Research Institute at Nationwide Children's \\ Hospital, 700 Children's Drive, Columbus, OH 43205, USA \\ ${ }^{2}$ Center for Injury Research and Policy, The Abigail Wexner Research Institute at Nationwide Children's \\ Hospital, 700 Children's Drive, Columbus, OH 43205, USA \\ ${ }^{3}$ College of Medicine, The Ohio State University, 370 West 9th Avenue, Columbus, OH 43210, USA \\ ${ }^{4}$ Department of Pediatric Surgery, Nationwide Children's Hospital, 700 Children's Drive, Columbus, OH \\ 43205, USA \\ ${ }^{5}$ Department of Pediatrics, The Ohio State University, 370 West $9^{\text {th }}$ Avenue, Columbus, OH 43210, USA
}

\section{Corresponding author:}

Henry Xiang, MD, MPH, PhD, MBA, Director of Center for Pediatric Trauma Research \& Director of Research Core/Center for Injury Research and Policy, Nationwide Children's Hospital, 700 Children's Drive, Columbus, Ohio 43205, henry.xiang@,nationwidechildrens.org, (614)-355-5893

\section{Funding Source:}

This work was supported by a grant from the Ohio Department of Public Safety Emergency Medical Services and Jonathan Lun received the COM Medical Student Research Scholarship (MDSRS) funded by the Samuel J. Roessler Memorial Scholarship.

\section{Declarations of Interest:}

None

\section{Abstract}

Importance: Virtual Reality (VR) gaming is considered a safe and effective alternative to standard pain alleviation in the hospital, we advocate for its use during repeated redressing at home.

Objective: This study will address the effectiveness and feasibility of the Virtual Reality Pain Alleviation Tool (VR-PAT) that was developed by the research team at the Nationwide Children's Hospital for repeated at-home burn dressing changes.

Design, Setting and Participants: Randomized clinical trial among patients recruited at the Nationwide Children's Hospital (NCH) outpatient burn clinic between September 2019 and June 2021. We included English-speaking burn patients 5-17 years old requiring daily dressing changes for at least one week after first outpatient dressing change. 
medRxiv preprint doi: https://doi.org/10.1101/2022.01.07.22268893; this version posted January 7, 2022. The copyright holder for this preprint (which was not certified by peer review) is the author/funder, who has granted medRxiv a license to display the preprint in perpetuity.

It is made available under a CC-BY-ND 4.0 International license .

Interventions: One group played an interactive VR-PAT game during dressing changes, while the other utilized standard distraction techniques available in the home for a week. Both child and caretaker were later asked to assess perceived pain. Those in the intervention group were asked to evaluate convenience and enjoyment of the VR-PAT game.

Outcomes: Patients were asked to rate perceived pain on a scale of 1-10, and caregivers were asked to rate observed pain on a scale of 1-10. For the VR-PAT group, patients were also asked to rate various aspects of the VR game on a scale of 1-10 and caregivers were asked questions assessing ease of use.

Conclusions: Subjects found the VR-PAT to be a useful distraction during home dressing changes and reported it be easy to implement. In the VR-PAT group, child and caregiver reported pain decreased as the week of dressing changes progressed and was lower than those in the control group after the fourth dressing change. Children playing the VR-PAT reported consistent happiness and fun as the week went on and increased realism and engagement, which means our results weren't just due to the novel experience of VR-PAT.

Trial Registration: ClinicalTrials.gov Identifier: NCT04548635 
medRxiv preprint doi: https://doi.org/10.1101/2022.01.07.22268893; this version posted January 7, 2022. The copyright holder for this preprint (which was not certified by peer review) is the author/funder, who has granted medRxiv a license to display the preprint in perpetuity.

It is made available under a CC-BY-ND 4.0 International license .

\section{$\underline{\text { Introduction }}$}

Since the turn of the century, treatment options for pediatric burn patients have taken significant strides. This is evidenced by a $48 \%$ decrease in mortality and $64 \%$ increase in patient referral to larger, more well-equipped institutions in the past 20 years. ${ }^{1}$ However, pediatric burns continue to be a serious public health issue. In 2019, the CDC reported that burns are the fourth leading cause of death due to unintentional injury in children ages $1-14 .^{2}$ A major area for improvement is in the field of pain management. This includes acute/nociceptive pain from both the initial burn and procedural pain from subsequent dressing changes. ${ }^{3}$

Dressing changes are often more painful than the initial burn and may require high-dose opioids. ${ }^{4}$ This is particularly concerning, as studies show a nationwide two-fold increase in pediatric mortality rate due to opioid poisonings since the early 2000 's. ${ }^{5}$ The danger of opioids must be balanced with the need for adequate pain relief. Repeated dressing-associated pain has been shown to increase anxiety and learned helplessness in pediatric patients. ${ }^{6,7}$ As a result, nonpharmacologic alternatives have risen to the forefront of pain management research. Methods such as hypnosis, cognitive behavioral therapy and distraction are now standard protocol in the hospital setting. ${ }^{8}$

Virtual Reality (VR) provides a much more immersive distraction than standard techniques such as muscle relaxation and toys. ${ }^{9}$ Multiple studies have demonstrated that VR distraction is clinically beneficial when compared with current standard of care. ${ }^{9-11}$ In addition to their efficacy, VR games are also rated by patients as enjoyable, user friendly and having few side effects. ${ }^{9}$ VR as a pain alleviation tool for burn victims is well-studied in the hospital, however there is little literature focusing on its use during at-home dressing changes. Furthermore, previous studies investigating VR gaming as a pain management dated back to 1980 and many of them used the bulky computer-based systems, which is not very practical for clinical implementation as well as at-home burn dressing change.

The lack of studies pertaining to the use of VR during at-home burn management is surprising, as recent advances in technology have allowed VR to be accessible, relatively inexpensive and common in 
gaming, education and medical care. ${ }^{12}$ From a clinical perspective, at-home VR has demonstrated utility in treatment of public speaking anxiety ${ }^{13}$, fall prevention in the elderly ${ }^{14}$ and neuromuscular rehabilitation. ${ }^{15}$ VR has also shown promise in terms of managing chronic pain. A 2017 study by Garrett et al. found that at-home VR therapy was effective in reducing short-term pain among patients with chronic conditions. ${ }^{16}$ The diverse use of VR in at-home care combined with its promise as a nonpharmacologic pain management tool makes it an ideal potential adjunct to standard home burn care.

National statistics reported that over 250,000 US children (0-17 years) suffer burn injuries every year. ${ }^{17}$ Over half of pediatric burn injuries seen in US emergency departments (EDs) are serious enough to merit referral to a burn center according to US and international guidelines. ${ }^{8,18}$ After being discharged from medical burn care facilities, at-home repeated burn dressing changes are often needed for 2-3 weeks. Dressing changes have been identified by pediatric patients as very painful, with opioid and anxiety medications often being prescribed. ${ }^{19,20}$ Furthermore, the pain experienced during burn dressing changes may cause distress to not only pediatric patients but also their caregivers. ${ }^{21}$ A painful experience can additionally serve as a stressor that significantly impacts patients' post-injury health outcomes. ${ }^{22,23}$ The latest research shows that repeated use of opioid medication for acute pain management is likely to increase the risk of long-term opioid use and risk of opioid addictions. ${ }^{24,25}$ The medical community in the US is diligently working to find the right balance between the risk of undertreating pain and causing unneeded suffering ${ }^{19,20}$ and the risk of over (or inappropriate) prescription of opioids. ${ }^{26}$ The "50 State Review on Opioid Related Policy", published in late 2017, reported that 11 states have laws or guidelines in place that encourage the use of non-opioid alternatives for pain treatment. ${ }^{27}$ The Ohio State Medical Board mandates that all prescriptions will need to carry documentation which "should indicate whether there are known and available non-opiate alternatives and why it has been determined not to utilize these alternatives". Therefore, there is a pressing need to seek non-pharmacological interventions for effective pain management in pediatric burn wound care. 
medRxiv preprint doi: https://doi.org/10.1101/2022.01.07.22268893; this version posted January 7, 2022. The copyright holder for this preprint (which was not certified by peer review) is the author/funder, who has granted medRxiv a license to display the preprint in perpetuity.

It is made available under a CC-BY-ND 4.0 International license .

Non-pharmacological pain management is widely utilized by pediatric clinicians as safe and affordable solutions for procedural acute pain management. ${ }^{28,29}$ According to the Cognitive-Affective Model of Pain, ${ }^{30}$ pain perception demands cognitive attention. Thus, effective non-pharmacological pain management requires the interruption of the cognitive route from the origin to pain perception, redirecting (distracting) a child's attention resources away from the painful procedure. VR has been demonstrated to effectively decrease pain and distress in a variety of settings, diverse populations (i.e. children as well as adults), ${ }^{31,32}$ and a wide range of pain conditions (i.e. acute, procedural, and chronic). ${ }^{33}$ Researchers have provided preliminary but convincing evidence that suggests the neurobiological interplay of brain cortices and neurochemistry, as well as emotional, cognitive, and attentional processes as the underlying mechanistic origin for VR analgesia. ${ }^{34}$ Gold et al. and other researchers have demonstrated that VR reduces pain signaling in this pain matrix that mimics, in part, the actions of opiates. ${ }^{33-36}$

Prior research confirmed that VR provides three unique advantages over traditional nonpharmacological interventions for pediatric burn patients. ${ }^{9,37}$ First, VR technology is capable of creating a three-dimensional immersive virtual environment (e.g. visual; auditory; interaction) for actively engaging the pediatric patients' attention in order to successfully interrupt the pain perception route, consistent with the Cognitive-Affective Model of Pain $^{29,38}$ and underlying mechanisms of pain management. The unique highly immersive experience of presence, interactivity, and embodiment offered by VR-based pain management is therefore distinct from and advantageous to common forms of distraction (i.e., bubbles; books; toys), passively watching television or movies, and playing a two-dimensional handheld video game or game console. Second, because the entire distraction process takes place within a safe, controlled, automated virtual environment ${ }^{39}$, VR-based pain management can be safely implemented in home settings. Third, previous researchers have developed VR pain distraction with burn patients in mind (e.g. snow world for burn dressing pain management) and preliminary positive results from pediatric and adult patient populations were published. Prior-generation computer-based VR pain distractions required large equipment costs as well as equipment setup and cleaning that required professional training, posing 
significant obstacles for the VR to be widely adopted in home settings. ${ }^{40}$ However, thanks to recent advancement in VR technology, VR-based pain distraction has evolved from expensive and cumbersome pieces of equipment to affordable, lightweight, mobile devices with sizes comparable to a smartphone. This reduction in the size and cost of smartphone-based VR games, coupled with significantly improved system stability and, importantly, accessibility, ${ }^{41}$ has opened the door to using VR widely for burn dressing pain management in home settings.

Recent meta-analysis and reviews of published studies in the past three decades have provided evidence that VR can effectively distract patients to reduce pain and anxiety across many settings. ${ }^{33,37,42-44}$ However, prior studies have not investigated the feasibility and barriers of VR games for pain management during at-home burn dressing changes. Furthermore, almost all of the existing studies used computer-based VR that is technologically and financially inaccessible to patient families for everyday use in the home.

In order the address gaps in previous research, our study aimed to 1) Examine the effect of VR pain alleviation tool (VR-PAT) on reducing pediatric burn patients' perceived pain during at-home dressing changes, 2) Examine the effect of VR-PAT on reducing pediatric patients' perceived pain during repeated home burn dressing changes, and 3) Examine the usability of VR-PAT during pediatric dressing changes in a home setting.

\section{$\underline{\text { Methods }}$}

This randomized control trial tested whether a smartphone VR-PAT effectively reduced pain during repeated pediatric burn dressing changes at home. We also qualitatively assessed the ease of setup and enjoyment of the program. From September 1, 2019 to May 30, 2021 (the end of the funding period), 35 patients were recruited from the outpatient burn clinic at Nationwide Children's Hospital $(\mathrm{NCH})$ and randomly assigned to either the VR group or the control group which used standard home distraction techniques. Inclusion criteria were (1) pediatric burn patients (5-17 years) who were receiving their first outpatient dressing change at the Nationwide Children's Outpatient Burn Clinic, (2) have a dressing that 
medRxiv preprint doi: https://doi.org/10.1101/2022.01.07.22268893; this version posted January 7, 2022. The copyright holder for this preprint (which was not certified by peer review) is the author/funder, who has granted medRxiv a license to display the preprint in perpetuity.

It is made available under a CC-BY-ND 4.0 International license.

requires daily changes at home for at least one week after their first $\mathrm{NCH}$ outpatient clinic dressing change, and (3) can communicate orally. Exclusion criteria include: (1) Any wounds that may interfere with study procedures, (2) Vision, hearing, or cognitive/motor impairments preventing valid administration of study measures, (3) History of motion sickness, seizure disorder, dizziness, or migraine headaches precipitated by visual auras, (4) Minors in foster care (5) Suspected child abuse, (6) Unable to communicate in English, or (7) Families who do not have access to a smartphone (due to the VR-PAT game requirements).

Over the study period, 313 patients were screened, and we found 145 patients to be eligible for all factors before knowing the dressing change and 65 of these patients meeting our criteria after learning the dressing type. A trained researcher approached 49 patients for participation and 35 patients consented/assented to this RCT. Of those recruited, 24 participants returned their surveys and completed the study. No other subjects were excluded from the study following recruitment (Figure 1). 


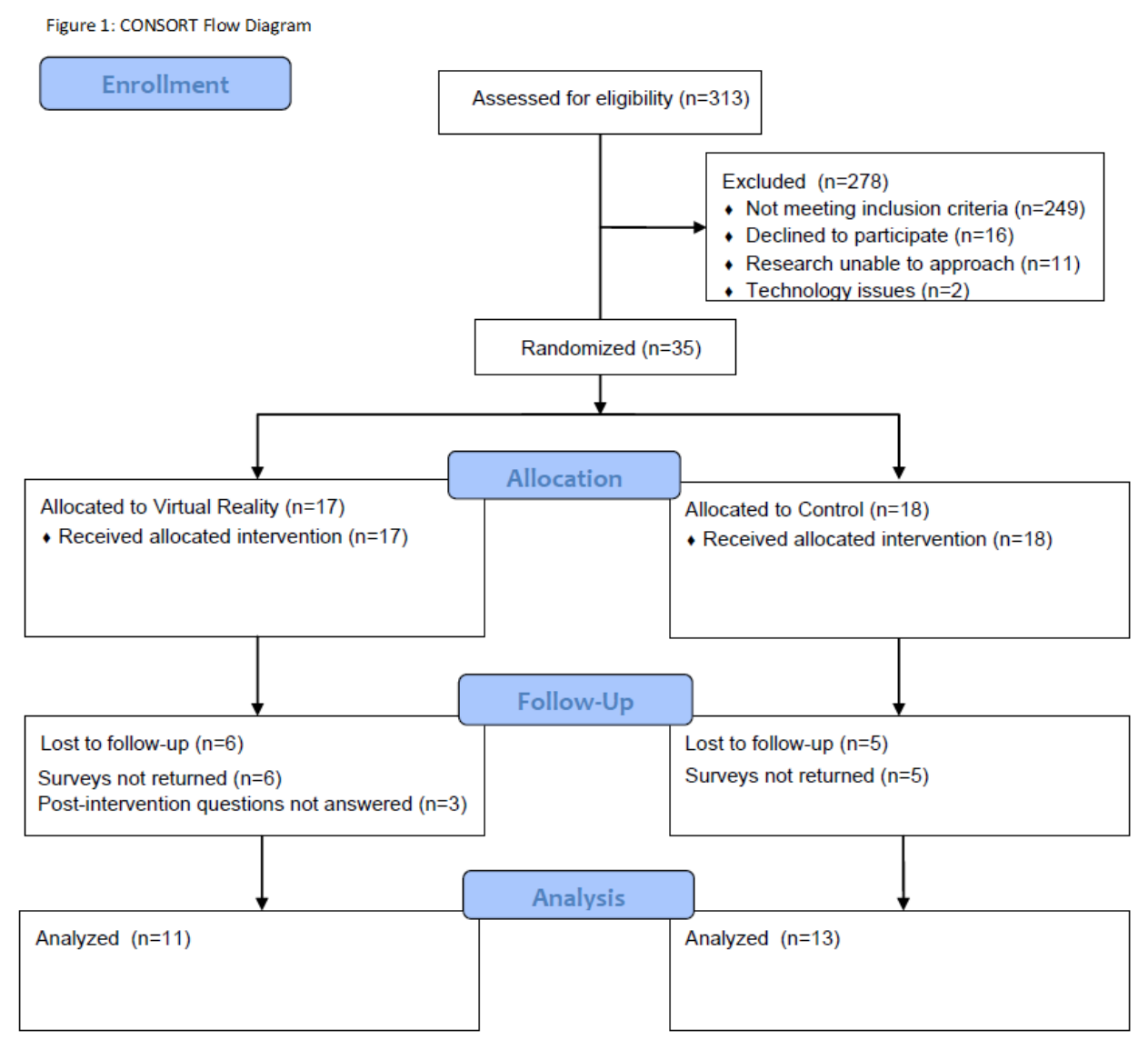

\section{Study Procedures}

Potential participants were identified via the Electronic Medical Record System and approached by a trained researcher at $\mathrm{NCH}$. After obtaining informed consent (and assent for participants age $\geq 9$ years), participants were asked baseline questions about their experience playing video games (days per week playing VR, console, or computer games) before being randomly assigned to either the VR-PAT or a standard of care control group using a 1:1 randomization scheme in Research Electronic Data Capture (REDCap) designed for our project. ${ }^{45,46}$ Every participant in the study was given a VR headset to bring home and the control group was instructed to complete the first week of dressing changes without the VR device. Participants and guardians were given up to eight surveys, to be completed each time a dressing change was necessary for up to one week and these surveys were then returned by mail in a pre-paid, selfaddressed envelope 
medRxiv preprint doi: https://doi.org/10.1101/2022.01.07.22268893; this version posted January 7, 2022. The copyright holder for this preprint (which was not certified by peer review) is the author/funder, who has granted medRxiv a license to display the preprint in perpetuity.

It is made available under a CC-BY-ND 4.0 International license .

\section{Child Surveys (self-reported)}

Participants self-rated overall pain, worst pain, and time spent thinking about pain on a scale of 1-10 (higher score means more pain). Patients in the VR group were also asked to rate their happiness, fun, engagement, and realism of the game on a scale of 1-10 (higher score means more helpful). They were also asked to report if the game made them feel not well.

\section{Guardian Surveys (self-reported)}

Guardians were also asked to report the participants overall pain and worst pain on a scale of 1-10 (higher score means more pain). Those in the VR group were asked to report time spent using the VR-PAT, whether the participant declined to use the VR, number of voluntary interruptions, whether the device was helpful and easy to use, and any pain medications used for the burn.

Finally, participants in the VR group were contacted after a week of home dressings to ask postintervention questions about what they liked about the game, didn't like about the game, and whether any part of the game or set-up was too hard.

Demographic information was pulled from the electronic medical record. This included date of birth, gender, race, ethnicity, burn date, visit date, percent total body surface area (TBSA), burn severity ( $1^{\text {st }}$, $2^{\text {nd }}$, or $3^{\text {rd }}$ degree), and body area burned.

\section{Interventions}

\section{$\underline{\text { VR-PAT group }}$}

Our VR-PAT consisted of a lightweight VR headset with a Virtual River Cruise game that is played on a smartphone. In our pilot study, ${ }^{47}$ we found that active VR (interacting with VR game) was significantly more beneficial than passive VR (watching the same VR game). Due to these findings, only active VR was used for our intervention group for this study. VR-PAT is a standalone game developed by the 
medRxiv preprint doi: https://doi.org/10.1101/2022.01.07.22268893; this version posted January 7, 2022. The copyright holder for this preprint (which was not certified by peer review) is the author/funder, who has granted medRxiv a license to display the preprint in perpetuity.

It is made available under a CC-BY-ND 4.0 International license .

Research Information Solutions and Innovation department at NCH and could be downloaded onto participants' smartphones using either a QR code or a dedicated website.

The Virtual River Cruise game involved piloting a boat towards snow-emitting statues on a riverbank. Additionally, a thermometer on the boat would drop in temperature to create a cooling effect whenever statues were collected, and a scoreboard next to the thermometer showed children the number of statues they had hit to provide reinforcement. Children steered the virtual boat by tilting their heads, creating an immersive and active experience without interfering with the burn dressing process.

\section{Control Group}

Our standard of care group was able to use any distraction available in the home, including toys, video games, mobile phone, and books. The control group asked not to use the VR device during the first week of dressing changes but encouraged to use it for any dressing following the study week.

Study Outcomes and Confounding Variables

\section{Primary Outcome}

Our primary outcome was pain associated with burn dressing changes. Pain scores were compared to subsequent surveys over the following week during repeated dressing changes. Secondary outcomes were time spent thinking about pain and caregiver-reported pain, both rated on a scale of 1-10. We also provided an opportunity for user feedback on VR's effectiveness and areas for improvement.

\section{Exploratory Outcome}

Both children and caretakers were asked to describe the perceived enjoyability and potential adverse effects of the VR. Additionally, patients were asked questions about prior experience with VR and other gaming systems.

Statistical Analysis 
medRxiv preprint doi: https://doi.org/10.1101/2022.01.07.22268893; this version posted January 7, 2022. The copyright holder for this preprint (which was not certified by peer review) is the author/funder, who has granted medRxiv a license to display the preprint in perpetuity.

It is made available under a CC-BY-ND 4.0 International license.

Demographic and burn characteristics were described using frequencies and percentages for the categorical variables and means and standard deviation (SD) for continuous variables. Mean, SD, and median were calculated for the primary outcome of reported pain (worst pain, overall pain, and time spent thinking of pain) across dressing changes. Child satisfaction (realism, engagement, happiness, and fun) was calculated as a mean across dressing changes. Qualitative data was collected at follow-up on the child's utilization experience and are reported as frequencies and percentages for how often these issues were reported. Data analyses were conducted in SAS version 9.4 (SAS Institute).

\section{$\underline{\text { Results }}$}

The majority of children in this study were male ( $\mathrm{n}=19)$, making up $64.7 \%$ of the VR group and $44.4 \%$ of the control group (Table 1). Most participants were also White, making up $88.2 \%$ of the VR group and $77.8 \%$ of the control group. Participants in the control group were slightly older, having a mean of 12.3 years compared to 10.7 years in the VR group. Both groups had small burns (median 1\% TBSA) and 16 participants in each group had a $2^{\text {nd }}$ degree burn. Participants in both groups played console and computer games before but had little to no experience with VR games. 
medRxiv preprint doi: https://doi.org/10.1101/2022.01.07.22268893; this version posted January 7, 2022. The copyright holder for this preprint (which was not certified by peer review) is the author/funder, who has granted medRxiv a license to display the preprint in perpetuity.

It is made available under a CC-BY-ND 4.0 International license .

Table 1: Demographics, burn characteristics and prior experience with games of study participants

\begin{tabular}{|c|c|c|}
\hline \multirow[b]{2}{*}{ Characteristics } & \multicolumn{2}{|c|}{ Intervention Group } \\
\hline & VR $(n=17)$ & Control $(n=18)$ \\
\hline \multicolumn{3}{|l|}{ Demographics } \\
\hline \multicolumn{3}{|l|}{ Gender, n (\%) } \\
\hline Male & $11(64.7)$ & $8(44.4)$ \\
\hline Female & $6(35.3)$ & $10(55.6)$ \\
\hline \multicolumn{3}{|l|}{ Race, n (\%) } \\
\hline White & $15(88.2)$ & $14(77.8)$ \\
\hline Black & $2(11.8)$ & $3(16.7)$ \\
\hline Other & $0(0)$ & $1(5.6)$ \\
\hline Age in years, mean (SD) & $10.7(2.9)$ & $12.3(3.3)$ \\
\hline \multicolumn{3}{|l|}{ Burn characteristics } \\
\hline \multicolumn{3}{|l|}{ Burn degree, n (\%) } \\
\hline Second & $16(94.1)$ & $16(88.9)$ \\
\hline Third & $1(5.9)$ & $2(11.1)$ \\
\hline TBSA (\%), median (IQR) & $1(1-2)$ & $1(0.5-1.5)$ \\
\hline \multicolumn{3}{|c|}{ Experience with games, median (IQR)* } \\
\hline VR weekly & $0(0-0)$ & $0(0-0)$ \\
\hline Console weekly & $2(0-5.5)$ & $2(0-7)$ \\
\hline Computer weekly & $7(2-7)$ & $5(2-7)$ \\
\hline
\end{tabular}

Of the 24 subjects who returned surveys, 11 were in the VR group and 13 were in the control group. There were 2 subjects who did not return medication surveys (Table 2). More subjects in the VR group reported using pain medications for the burn injury in dressings 1-5 than subjects in the control group but did not use any medications after dressing number 5. Of all the medications used, the vast majority were over the counter medications such as acetaminophen or ibuprofen. 
medRxiv preprint doi: https://doi.org/10.1101/2022.01.07.22268893; this version posted January 7, 2022. The copyright holder for this preprint (which was not certified by peer review) is the author/funder, who has granted medRxiv a license to display the preprint in perpetuity.

It is made available under a CC-BY-ND 4.0 International license .

Table 2: Reported pain medication use by dressing number and intervention group

\begin{tabular}{|c|c|c|c|c|c|c|c|c|}
\hline \multirow[b]{2}{*}{ Dressing \# } & \multicolumn{4}{|c|}{ VR, N (\%) } & \multicolumn{4}{|c|}{ Control, N (\%) } \\
\hline & Total & No & Yes & Missing & Total & No & Yes & Missing \\
\hline 1 & 11 & $3(27.3)$ & $6(54.6)$ & $2(18.2)$ & 13 & $10(76.9)$ & $3(23.1)$ & $0(0.0)$ \\
\hline 2 & 11 & $4(36.4)$ & $5(45.5)$ & $2(18.2)$ & 13 & $10(76.9)$ & $3(23.1)$ & $0(0.0)$ \\
\hline 3 & 9 & $4(44.4)$ & $4(44.4)$ & $1(11.1)$ & 13 & $11(84.6)$ & $2(15.4)$ & $0(0.0)$ \\
\hline 4 & 8 & $5(62.5)$ & $2(25.0)$ & $1(12.5)$ & 13 & $10(76.9)$ & $3(23.1)$ & $0(0.0)$ \\
\hline 5 & 8 & $6(75.0)$ & $1(12.5)$ & $1(12.5)$ & 13 & $12(92.3)$ & $1(7.7)$ & $0(0.0)$ \\
\hline 6 & 5 & $5(100.0)$ & $0(0.0)$ & $0(0.0)$ & 11 & $9(81.8)$ & $2(18.2)$ & $0(0.0)$ \\
\hline 7 & 5 & $5(100.0)$ & $0(0.0)$ & $0(0.0)$ & 8 & $7(87.5)$ & $1(12.5)$ & $0(0.0)$ \\
\hline 8 & 4 & $3(75.0)$ & $0(0.0)$ & $1(25.0)$ & 6 & $5(83.3)$ & $1(16.7)$ & $0(0.0)$ \\
\hline
\end{tabular}

* Only 1 subject used opioid medications. All other reported medications were either Acetaminophen or Ibuprofen

Subjects in the VR group completed at least 2 dressing changes while subjects in the control group completed at least 5 dressing changes (Table 3). In the VR group, the mean child reported worst pain ranged from 3.6 (standard deviation (SD) 2.7) at the 1st dressing to 0.3 (SD 0.5) at the 8th dressing and in the control group, the range was 3.0 (SD 2.6) at the 1st dressing to 2.3 (SD 2.7) at the 8th dressing. Overall pain ranged from mean $3.2(\mathrm{SD} 2.4)$ at the $1^{\text {st }}$ dressing to 0.3 (SD 0.5) at the $8^{\text {th }}$ dressing in the VR group and 2.9 (SD 2.3) at the $1^{\text {st }}$ dressing to 2.2 (SD 2.4) at the $8^{\text {th }}$ dressing. The mean time spent thinking about pain ranged from $3.6(\mathrm{SD} 4.1)$ at the $1^{\text {st }}$ dressing to 0.3 (SD 0.3) at the $8^{\text {th }}$ dressing in the VR group and 3.5 (SD 3.6) at the $1^{\text {st }}$ dressing to 1.7 (SD 2.1) at the $8^{\text {th }}$ dressing in the control group. Children in the VR group reported less pain following the $4^{\text {th }}$ dressing across worst pain, overall pain, and time spent thinking about pain (Figure 2). 
Table 3: Child reported pain by dressing number and intervention group

\begin{tabular}{|c|c|c|c|c|c|c|c|c|}
\hline \multirow[b]{2}{*}{ Dressing \# } & \multicolumn{4}{|c|}{ VR } & \multicolumn{4}{|c|}{ Control } \\
\hline & $\mathrm{NObs}$ & Mean & $\begin{array}{c}\text { Standard } \\
\text { Deviation }\end{array}$ & Median & $\mathrm{NObs}$ & Mean & $\begin{array}{l}\text { Standard } \\
\text { Deviation }\end{array}$ & Median \\
\hline \multicolumn{9}{|l|}{ Worst Pain } \\
\hline 1 & 11 & 3.6 & 2.7 & 3 & 13 & 3.0 & 2.6 & 3 \\
\hline 2 & 11 & 4.3 & 2.7 & 5 & 13 & 3.3 & 2.5 & 3 \\
\hline 3 & 9 & 2.8 & 2.1 & 3 & 13 & 2.7 & 2.7 & 2 \\
\hline 4 & 8 & 2.8 & 2.8 & 2 & 13 & 2.6 & 3.0 & 2 \\
\hline 5 & 8 & 1.0 & 1.5 & 0 & 13 & 1.9 & 2.8 & 1 \\
\hline 6 & 6 & 0.7 & 1.2 & 0 & 11 & 2.6 & 3.2 & 1 \\
\hline 7 & 5 & 0.2 & 0.5 & 0 & 8 & 2.8 & 3.1 & 2 \\
\hline 8 & 4 & 0.3 & 0.5 & 0 & 6 & 2.3 & 2.7 & 2 \\
\hline \multicolumn{9}{|c|}{ Overall Pain } \\
\hline 1 & 11 & 3.2 & 2.4 & 7 & 13 & 2.9 & 2.3 & 6 \\
\hline 2 & 11 & 3.0 & 2.3 & 7 & 13 & 2.7 & 1.9 & 6 \\
\hline 3 & 9 & 2.1 & 1.7 & 5 & 13 & 2.2 & 2.5 & 9 \\
\hline 4 & 8 & 2.4 & 2.4 & 8 & 13 & 2.1 & 2.5 & 8 \\
\hline 5 & 8 & 0.6 & 0.8 & 2 & 13 & 1.8 & 3.1 & 10 \\
\hline 6 & 6 & 0.5 & 0.8 & 2 & 11 & 2.1 & 2.9 & 8 \\
\hline 7 & 5 & 0.2 & 0.5 & 1 & 8 & 2.3 & 2.4 & 5 \\
\hline 8 & 4 & 0.3 & 0.5 & 1 & 6 & 2.2 & 2.4 & 5 \\
\hline \multicolumn{9}{|c|}{ Time Spent Thinking about Pain } \\
\hline 1 & 11 & 3.6 & 4.1 & 2.5 & 13 & 3.5 & 3.6 & 2 \\
\hline 2 & 11 & 3.6 & 3.6 & 2.5 & 13 & 2.8 & 2.8 & 1 \\
\hline 3 & 9 & 3.1 & 3.6 & 2 & 13 & 2.7 & 3.1 & 1 \\
\hline 4 & 8 & 2.8 & 3.3 & 1.5 & 13 & 2.4 & 4.0 & 0 \\
\hline 5 & 8 & 0.4 & 0.8 & 0 & 13 & 1.9 & 3.0 & 1 \\
\hline 6 & 6 & 0.5 & 0.8 & 0 & 11 & 2.2 & 2.9 & 0 \\
\hline 7 & 5 & 1.0 & 1.7 & 0 & 8 & 2.6 & 3.2 & 1 \\
\hline 8 & 4 & 0.3 & 0.5 & 0 & 6 & 1.7 & 2.1 & 1 \\
\hline
\end{tabular}

Abbreviations: N Obs, number of observations 
Figure 2: Child reported pain by dressing number and intervention group
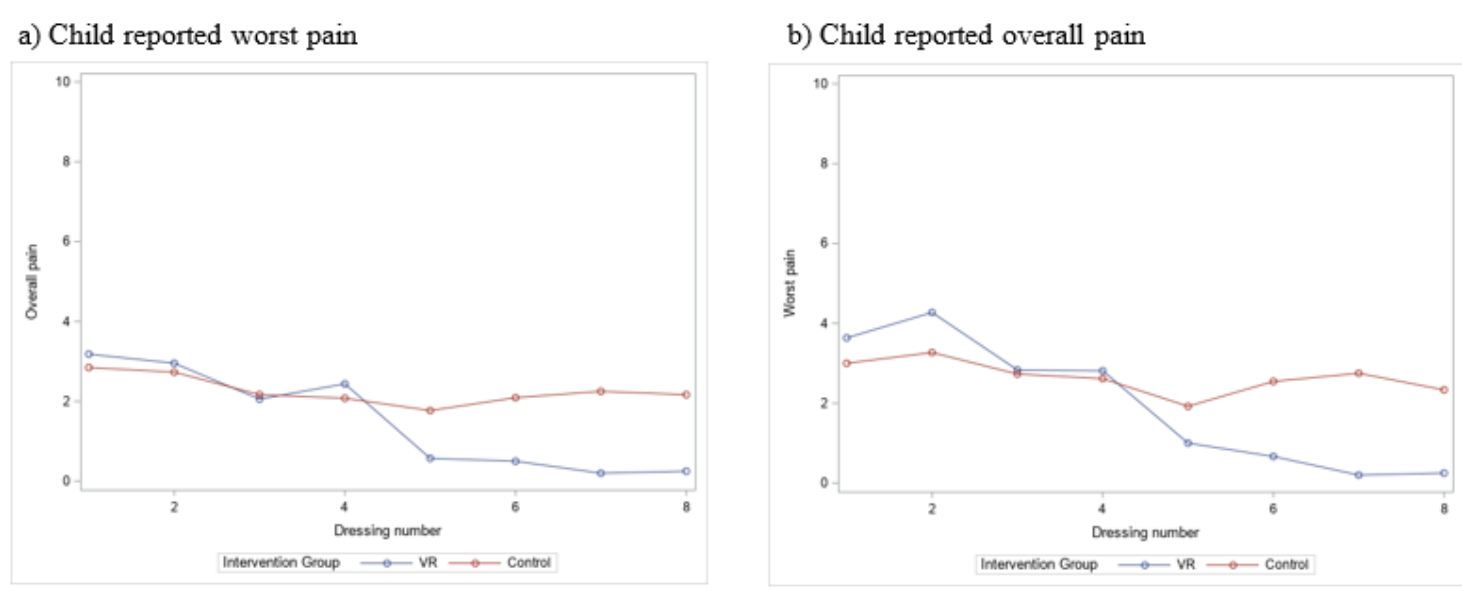

c) Child reported time thinking about pain

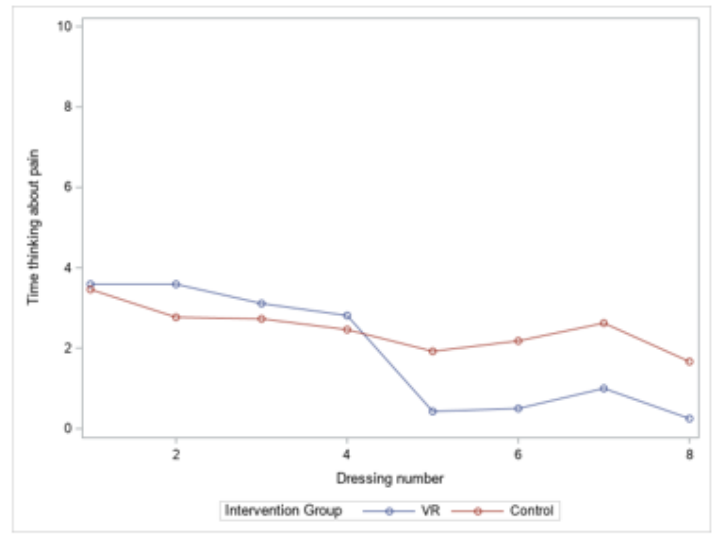

Caregiver reported pain followed a similar trend as the child report pain (Table 4). In the VR group, the mean caregiver reported worst pain ranged from 4.1 (SD 3.0) at the 1st dressing to 0.0 (SD 0.0) at the 8th dressing and in the control group, the range was 2.9 (SD 2.8) at the 1st dressing to 2.7 (SD 3.0) at the 8th dressing. Overall pain ranged from mean $3.2(\mathrm{SD} 2.6)$ at the $1^{\text {st }}$ dressing to $0.0(\mathrm{SD} 0.0)$ at the $8^{\text {th }}$ dressing in the VR group and 2.4 (SD 2.1) at the $1^{\text {st }}$ dressing to 2.3 (SD 2.6) at the $8^{\text {th }}$ dressing. Caregivers in the VR group also reported less pain following the $4^{\text {th }}$ dressing across worst pain and overall pain (Figure 3). 
Table 4: Caregiver reported pain by dressing number and intervention group

\begin{tabular}{|c|c|c|c|c|c|c|c|c|}
\hline \multirow[b]{2}{*}{ Dressing \# } & \multicolumn{4}{|c|}{ VR } & \multicolumn{4}{|c|}{ Control } \\
\hline & N Obs & Mean & $\begin{array}{l}\text { Standard } \\
\text { Deviation }\end{array}$ & Median & $\mathrm{NObs}$ & Mean & $\begin{array}{c}\text { Standard } \\
\text { Deviation }\end{array}$ & Median \\
\hline \multicolumn{9}{|l|}{ Worst Pain } \\
\hline 1 & 11 & 4.1 & 3.0 & 3 & 13 & 2.9 & 2.8 & 3 \\
\hline 2 & 10 & 3.9 & 2.5 & 3 & 13 & 3.5 & 2.8 & 4 \\
\hline 3 & 9 & 2.8 & 2.2 & 2 & 13 & 3.0 & 2.9 & 3 \\
\hline 4 & 8 & 2.7 & 2.5 & 2.3 & 13 & 2.5 & 3.0 & 2 \\
\hline 5 & 7 & 1.0 & 1.4 & 0 & 13 & 2.0 & 3.2 & 1 \\
\hline 6 & 6 & 0.2 & 0.5 & 0 & 11 & 2.5 & 3.4 & 0 \\
\hline 7 & 5 & 0.2 & 0.5 & 0 & 8 & 2.5 & 2.8 & 2 \\
\hline 8 & 4 & 0.0 & 0.0 & 0 & 6 & 2.7 & 3.0 & 2 \\
\hline \multicolumn{9}{|c|}{ Overall Pain } \\
\hline 1 & 11 & 3.2 & 2.6 & 2.5 & 13 & 2.4 & 2.1 & 2 \\
\hline 2 & 10 & 3.2 & 2.1 & 2 & 13 & 2.8 & 2.2 & 3 \\
\hline 3 & 9 & 2.3 & 1.6 & 2 & 13 & 2.2 & 2.1 & 2 \\
\hline 4 & 8 & 2.3 & 2.0 & 1.5 & 13 & 2.0 & 2.6 & 1 \\
\hline 5 & 7 & 0.7 & 1.1 & 0 & 13 & 1.7 & 2.9 & 0 \\
\hline 6 & 6 & 0.5 & 0.8 & 0 & 11 & 2.0 & 2.8 & 0 \\
\hline 7 & 5 & 0.2 & 0.5 & 0 & 8 & 2.1 & 2.3 & 2 \\
\hline 8 & 4 & 0.0 & 0.0 & 0 & 6 & 2.3 & 2.6 & 2 \\
\hline
\end{tabular}

Figure 3: Caregiver reported pain by dressing change and intervention group

a) Caregiver reported worst pain

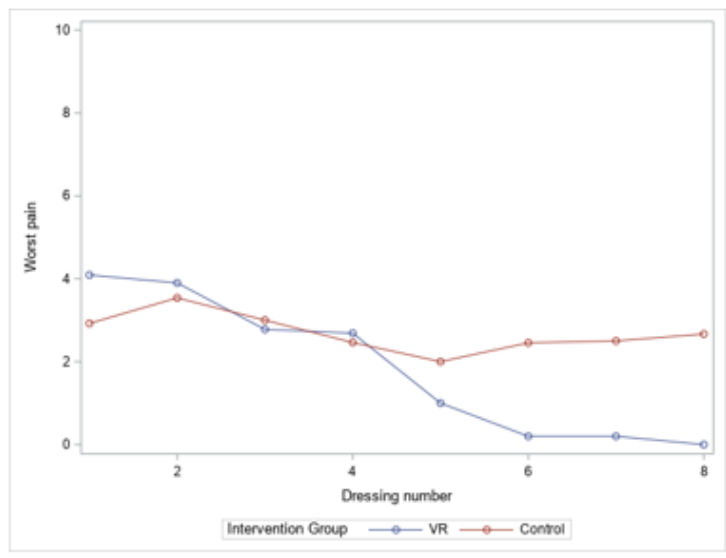

b) Caregiver reported overall pain

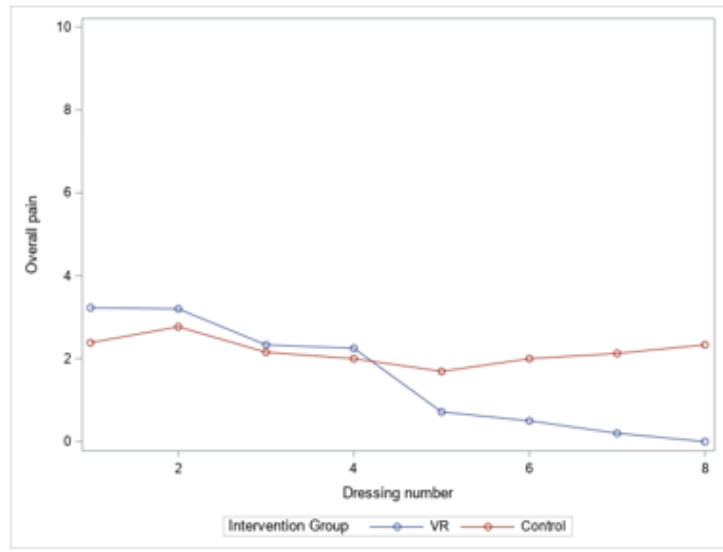

All children in the VR group reported their satisfaction with the VR-PAT after each dressing

(Figure 4). As dressing changes progressed over time, children reported increased realism (Did you feel like you were inside the game?) and engagement (How engaging did you think the game was?) with the 
medRxiv preprint doi: https://doi.org/10.1101/2022.01.07.22268893; this version posted January 7, 2022. The copyright holder for this preprint (which was not certified by peer review) is the author/funder, who has granted medRxiv a license to display the preprint in perpetuity.

It is made available under a CC-BY-ND 4.0 International license .

VR-PAT. Both realism and engagement started at a mean of $>5$ at the first dressing and increased to $>7$ at the last dressing. Children's happiness (Are you happy with the game?) and fun (How much fun did you have with it?) stayed constant at a mean of $>6$ across the week of dressings.

Figure 4: Child self-reported satisfaction with VR-PAT

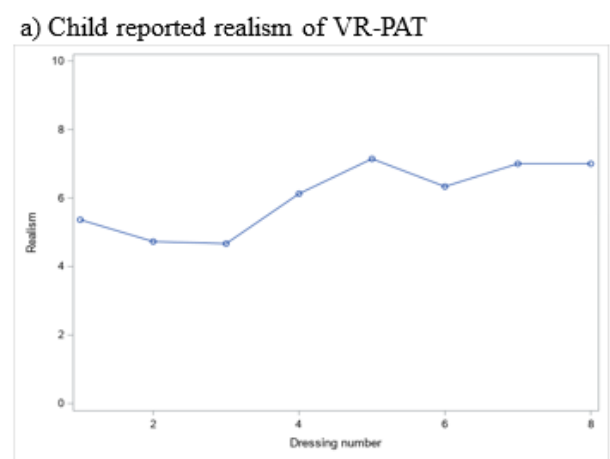

b) Child reported engagement with VR-PAT

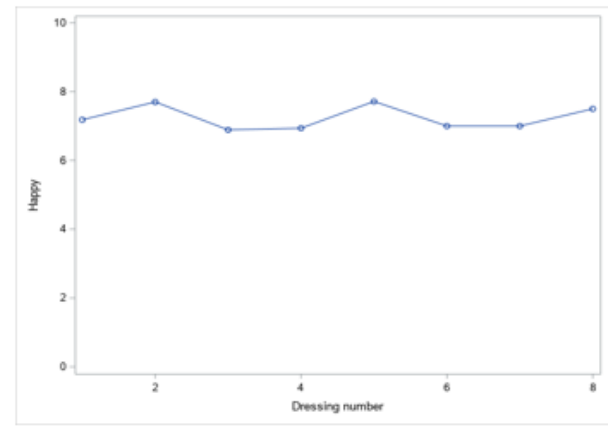

c) Child reported happy to use VR-PAT
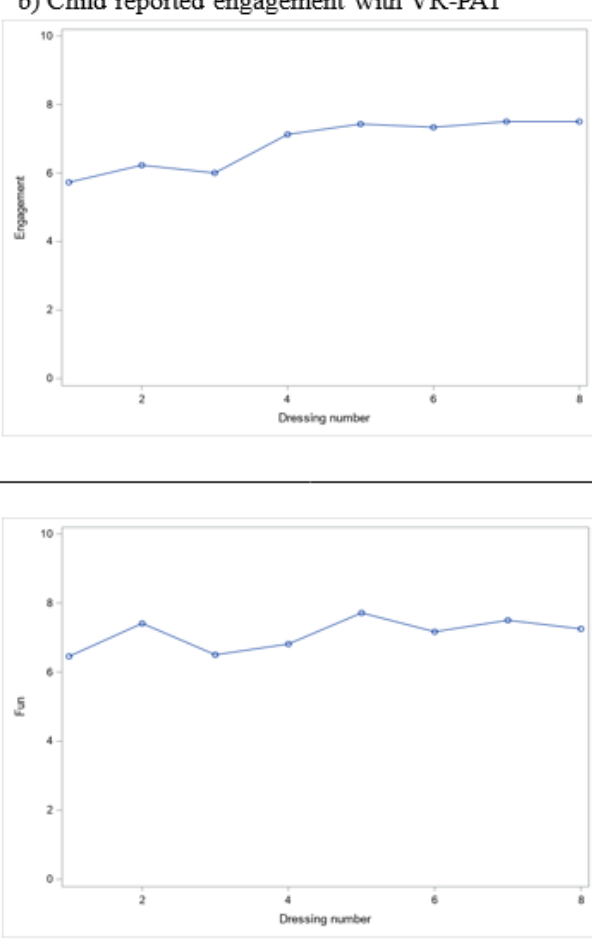

d) Child reported fun with VR-PAT

Following the week of dressing changes, children in the VR group were asked about their experience using the VR-PAT (Table 5). When asked about what they liked about the VR game, 54.5\% liked the game itself, $36.4 \%$ liked that it was a distraction, and $27.3 \%$ found the VR-PAT to be calming. When asked what they did not like about the VR game, the most common responses were a desire for more levels or goals $(36.4 \%)$ or nothing $(27.3 \%)$. Only one child didn't understand how to play the game at first. Finally, children were asked if there were any challenges with the VR-PAT and the majority did not express any challenges (54.5\%). Of those who did report challenges, there were some technological issues with downloading the game application (18.2\%), getting the system set-up (18.2\%), and one found the game to be difficult to play $(9.1 \%)$. 
medRxiv preprint doi: https://doi.org/10.1101/2022.01.07.22268893; this version posted January 7, 2022. The copyright holder for this preprint (which was not certified by peer review) is the author/funder, who has granted medRxiv a license to display the preprint in perpetuity.

It is made available under a CC-BY-ND 4.0 International license .

Table 5: Child self-reported VR-PAT utilization experience

\begin{tabular}{lc}
\hline & $\mathrm{N}(\%)$ \\
\hline What do you like about the VR game?* & \\
Playing the game & $6(54.5)$ \\
Distraction/not thinking about pain & $4(36.4)$ \\
Calming & $3(27.3)$ \\
What do you not like about the VR game? & \\
Wanted to stop boat or steer & $2(18.2)$ \\
Wanted more levels or goals & $4(36.4)$ \\
Didn't understand how to play at first & $1(9.1)$ \\
Wanted to watch dressing & $1(9.1)$ \\
Nothing & $3(27.3)$ \\
& \\
Challenges faced during VR-PAT utilization & $1(9.1)$ \\
Game was difficult & $2(18.2)$ \\
App download challenges & $2(18.2)$ \\
Setting-up the system & $6(54.5)$ \\
No challenges &
\end{tabular}

\section{$\underline{\text { Discussion }}$}

Our study was mostly made up of male, White children with second degree burns, which is consistent with other burns studies. ${ }^{1}$ The number of subjects using pain medication for dressing changes was also consistent with our previous research. ${ }^{47}$ Interestingly, children using VR-PAT reported slightly more pain than those in the control group at the beginning of the week, but they reported less pain following the $4^{\text {th }}$ dressing while those in the control group stayed fairly consistent. Caregiver reported pain followed a similar trajectory across both intervention groups. All subjects did not complete the same number of surveys, so future analyses should control for dressing numbers, injury severity, age, and medication use. We also saw that children in the VR-PAT group did not report decreasing happiness or fun as the week went on and, in fact, reported increased realism and engagement. There has been some concern in the virtual reality research community that the novelty of virtual reality would wear off with increased exposure, but we found the opposite to be true in this study. This is an encouraging finding for the effectiveness of using virtual reality as a pain distraction tool for burn injuries, as these typically require more than one painful procedure. Finally, children provided valuable feedback about the usefulness of using VR at home. Subjects enjoyed playing the game and felt that it helped to be distracted 
medRxiv preprint doi: https://doi.org/10.1101/2022.01.07.22268893; this version posted January 7, 2022. The copyright holder for this preprint (which was not certified by peer review) is the author/funder, who has granted medRxiv a license to display the preprint in perpetuity.

It is made available under a CC-BY-ND 4.0 International license .

from the dressing change. The things subjects did not like are important to know when either designing a VR game or choosing an existing game for this purpose. We chose to design a game that could be easily used across the age spectrum, but we learned that it may have been too simplistic, particularly for older children. Some children also prefer to be involved in the dressing change process, so having an immersive distraction is actually not preferrable to these children (one child reported this desire in our study). Most subjects in our study found the VR-PAT easy to use, but several important challenges were mentioned, particularly related to the technology and downloading of the app. The one person who found the game to be too difficult was one of the youngest participants in our study (5 years old), further justifying the lower bound of our age range for inclusion. Importantly, no children found the VR-PAT too difficult to use and stopped using because of this.

We faced several unexpected challenges during this randomized controlled trial. First, summers are the time of year where hospitals usually see the highest numbers of burn injuries in our specified age range. We missed the Summer 2019 due to difficulties in setting up the platform that would allow subjects to download the game app, which wasn't ready until late August 2019. Second, we encountered multiple changes in Apple's operating platform security surrounding downloading third party apps, which required our RISI team to change how the VR app could be downloaded onto an iPhone. These changes required complicated workarounds that meant we could not recruit iPhone users for periods of time. A consideration for future studies would be to host the app on Apple's App Store or Android's Google Play Store which makes downloading apps easier and could circumvent some of these issues. Third, we missed five months (March - August) in 2020, which included the summer, due to an NCH pause on in-person recruitment because of COVID-19. Fourth, COVID-19 resulted in institutional changes to in-person research which shifted our study to limit as much patient contact as possible. The best way to do this was to ask participants to mail their surveys back in a pre-paid, self-addressed envelope and we made three reminder calls to families. Unfortunately, we experienced a higher rate of loss to follow-up ( $\mathrm{n}=10)$ after making this change and we attribute it to families forgetting to mail surveys and United States Postal 
medRxiv preprint doi: https://doi.org/10.1101/2022.01.07.22268893; this version posted January 7, 2022. The copyright holder for this preprint (which was not certified by peer review) is the author/funder, who has granted medRxiv a license to display the preprint in perpetuity.

It is made available under a CC-BY-ND 4.0 International license.

Service (USPS) slowdowns. We believe that future studies should request surveys to be returned in person or allow families to e-mail their survey responses. Finally, there were a number of patients receiving either a long-term dressing or no dressing than we expected, which reduced the number of eligible patients. Our outpatient clinic did not have data on this prior to conducting this study, so this is something we have learned to take into consideration for future studies.

Our recommendation based on our experience conducting this study is that VR should be considered as a distraction method for home burn dressing changes. Since this is such an important topic in terms of pediatric burn care, our plan is to continue recruitment of this study until we have results for 60 subjects ( $n=30$ per intervention group), so that we can strengthen our results and achieve the study power. We recommend that future virtual reality studies consider technology issues (like changes in smartphone operating systems), reducing loss to follow-up, and time required to recruit subjects.

\section{$\underline{\text { Acknowledgements }}$}

Special thanks to Rohali Keesari, PharmD, MPH who assisted with data analysis, Simon Lin MD, MBA for support with the VR game, and the nurses and staff members at the Nationwide Children's Hospital Outpatient Burn Clinic for providing support during the patient recruitment. Without their support and help, this research study could not have been successful. 
medRxiv preprint doi: https://doi.org/10.1101/2022.01.07.22268893; this version posted January 7, 2022. The copyright holder for this preprint (which was not certified by peer review) is the author/funder, who has granted medRxiv a license to display the preprint in perpetuity.

It is made available under a CC-BY-ND 4.0 International license .

\section{References}

1. Armstrong M, Wheeler KK, Shi J, et al. Epidemiology and trend of US pediatric burn hospitalizations, 2003-2016. Burns. 2021;47(3):551-559.

2. Centers for Disease Control and Prevention. WISQARS Data Visualization. 2019; https://wisqars-viz.cdc.gov:8006/lcd/home.

3. Griggs C, Goverman J, Bittner EA, et al. Sedation and Pain Management in Burn Patients. Clin Plast Surg. 2017;44(3):535-540.

4. Hansen JK, Voss J, Ganatra H, et al. Sedation and Analgesia During Pediatric Burn Dressing Change: A Survey of American Burn Association Centers. J Burn Care Res. 2019;40(3):287-293.

5. Gaither JR, Shabanova V, Leventhal JM. US National Trends in Pediatric Deaths From Prescription and Illicit Opioids, 1999-2016. JAMA Network Open. 2018;1(8):e186558-e186558.

6. Fagin A, Palmieri TL. Considerations for pediatric burn sedation and analgesia. Burns Trauma. 2017;5:28.

7. Stoddard FJ, Sheridan RL, Saxe GN, et al. Treatment of pain in acutely burned children. J Burn Care Rehabil. 2002;23(2):135-156.

8. Gamst-Jensen H, Vedel PN, Lindberg-Larsen VO, et al. Acute pain management in burn patients: appraisal and thematic analysis of four clinical guidelines. Burns. 2014;40(8):1463-1469.

9. Dascal J, Reid M, IsHak WW, et al. Virtual Reality and Medical Inpatients: A Systematic Review of Randomized, Controlled Trials. Innov Clin Neurosci. 2017;14(1-2):14-21.

10. Kipping B, Rodger S, Miller K, et al. Virtual reality for acute pain reduction in adolescents undergoing burn wound care: a prospective randomized controlled trial. Burns. 2012;38(5):650657.

11. Schmitt YS, Hoffman HG, Blough DK, et al. A randomized, controlled trial of immersive virtual reality analgesia, during physical therapy for pediatric burns. Burns. 2011;37(1):61-68. 
medRxiv preprint doi: https://doi.org/10.1101/2022.01.07.22268893; this version posted January 7, 2022. The copyright holder for this preprint (which was not certified by peer review) is the author/funder, who has granted medRxiv a license to display the preprint in perpetuity.

It is made available under a CC-BY-ND 4.0 International license .

12. Bailenson J. Experience on Demand: What Virtual Reality Is, How It Works, and What It Can Do.

W. W. Norton; 2018.

13. Stupar-Rutenfrans S, Ketelaars LEH, van Gisbergen MS. Beat the Fear of Public Speaking: Mobile $360^{\circ}$ Video Virtual Reality Exposure Training in Home Environment Reduces Public Speaking Anxiety. Cyberpsychol Behav Soc Netw. 2017;20(10):624-633.

14. Arlati S, Colombo V, Spoladore D, et al. A Social Virtual Reality-Based Application for the Physical and Cognitive Training of the Elderly at Home. Sensors (Basel). 2019;19(2).

15. Villiger M, Liviero J, Awai L, et al. Home-Based Virtual Reality-Augmented Training Improves Lower Limb Muscle Strength, Balance, and Functional Mobility following Chronic Incomplete Spinal Cord Injury. Front Neurol. 2017;8:635.

16. Garrett B, Taverner T, McDade P. Virtual Reality as an Adjunct Home Therapy in Chronic Pain Management: An Exploratory Study. JMIR Med Inform. 2017;5(2):e11.

17. Burn Foundation. Pediatric Burn Fact Sheet.

http://www.burnfoundation.org/programs/resource.cfm?c=1\&a=12. Accessed January 30, 2019.

18. Johnson SA, Shi J, Groner JI, et al. Inter-facility transfer of pediatric burn patients from U.S. Emergency Departments. Burns. 2016;42(7):1413-1422.

19. Choinière M, Melzack R, Rondeau J, et al. The pain of burns: characteristics and correlates. $J$ Trauma. 1989;29(11):1531-1539.

20. Solowiej K, Upton D. Painful dressing changes for chronic wounds: assessment and management. Br J Nurs. 2012;21(20):20, 22, 24-25.

21. Singleton A, Preston RJ, Cochran A. Sedation and analgesia for critically ill pediatric burn patients: the current state of practice. J Burn Care Res. 2015;36(3):440-445.

22. Das DA, Grimmer KA, Sparnon AL, et al. The efficacy of playing a virtual reality game in modulating pain for children with acute burn injuries: a randomized controlled trial [ISRCTN87413556]. BMC Pediatr. 2005;5(1):1. 
medRxiv preprint doi: https://doi.org/10.1101/2022.01.07.22268893; this version posted January 7, 2022. The copyright holder for this preprint (which was not certified by peer review) is the author/funder, who has granted medRxiv a license to display the preprint in perpetuity.

It is made available under a CC-BY-ND 4.0 International license .

23. Smith JS, Smith KR, Rainey SL. The Psychology of Burn Care. Journal of Trauma Nursing | JTN. 2006;13(3):105-106.

24. Harbaugh CM, Lee JS, Hu HM, et al. Persistent Opioid Use Among Pediatric Patients After Surgery. Pediatrics. 2018;141(1):e20172439.

25. Shah A, Hayes CJ, Martin BC. Characteristics of Initial Prescription Episodes and Likelihood of Long-Term Opioid Use - United States, 2006-2015. MMWR Morb Mortal Wkly Rep. 2017;66(10):265-269.

26. National Academies of Sciences Engineering Medicine. Pain Management and the Opioid Epidemic: Balancing Societal and Individual Benefits and Risks of Prescription Opioid Use. Washington, DC: The National Academies Press; 2017.

27. Martz M, Ruberto I, Ampadu L, et al. 50 State Review on Opioid Related Policy. 2017; www.azhealth.gov/opioid2017.

28. Hua Y, Qiu R, Yao WY, et al. The Effect of Virtual Reality Distraction on Pain Relief During Dressing Changes in Children with Chronic Wounds on Lower Limbs. Pain Manag Nurs. 2015;16(5):685-691.

29. Malloy KM, Milling LS. The effectiveness of virtual reality distraction for pain reduction: a systematic review. Clin Psychol Rev. 2010;30(8):1011-1018.

30. Eccleston C, Crombez G. Pain demands attention: a cognitive-affective model of the interruptive function of pain. Psychol Bull. 1999;125(3):356-366.

31. Arane K, Behboudi A, Goldman RD. Virtual reality for pain and anxiety management in children. Can Fam Physician. 2017;63(12):932-934.

32. Pourmand A, Davis S, Marchak A, et al. Virtual Reality as a Clinical Tool for Pain Management. Curr Pain Headache Rep. 2018;22(8):53. 
medRxiv preprint doi: https://doi.org/10.1101/2022.01.07.22268893; this version posted January 7, 2022. The copyright holder for this preprint (which was not certified by peer review) is the author/funder, who has granted medRxiv a license to display the preprint in perpetuity.

It is made available under a CC-BY-ND 4.0 International license .

33. Gupta A, Scott K, Dukewich M. Innovative Technology Using Virtual Reality in the Treatment of Pain: Does It Reduce Pain via Distraction, or Is There More to It? Pain Medicine. 2017;19(1):151-159.

34. Triberti S, Repetto C, Riva G. Psychological factors influencing the effectiveness of virtual reality-based analgesia: a systematic review. Cyberpsychol Behav Soc Netw. 2014;17(6):335-345.

35. Gold JI, Belmont KA, Thomas DA. The neurobiology of virtual reality pain attenuation. Cyberpsychol Behav. 2007;10(4):536-544.

36. Ossipov MH, Dussor GO, Porreca F. Central modulation of pain. The Journal of Clinical Investigation. 2010;120(11):3779-3787.

37. Won AS, Bailey J, Bailenson J, et al. Immersive Virtual Reality for Pediatric Pain. Children (Basel). 2017;4(7).

38. Mott J, Bucolo S, Cuttle L, et al. The efficacy of an augmented virtual reality system to alleviate pain in children undergoing burns dressing changes: a randomised controlled trial. Burns. 2008;34(6):803-808.

39. Indovina P, Barone D, Gallo L, et al. Virtual Reality as a Distraction Intervention to Relieve Pain and Distress During Medical Procedures: A Comprehensive Literature Review. Clin J Pain. 2018;34(9):858-877.

40. Markus LA, Willems KE, Maruna CC, et al. Virtual reality: feasibility of implementation in a regional burn center. Burns. 2009;35(7):967-969.

41. Furlow B. Cautious optimism for medical virtual reality. The Lancet Child \& Adolescent Health. 2018;2(2):88-89.

42. Gold JI, Mahrer NE. Is Virtual Reality Ready for Prime Time in the Medical Space? A Randomized Control Trial of Pediatric Virtual Reality for Acute Procedural Pain Management. $J$ Pediatr Psychol. 2018;43(3):266-275. 
medRxiv preprint doi: https://doi.org/10.1101/2022.01.07.22268893; this version posted January 7, 2022. The copyright holder for this preprint (which was not certified by peer review) is the author/funder, who has granted medRxiv a license to display the preprint in perpetuity. It is made available under a CC-BY-ND 4.0 International license.

43. Pourmand A, Davis S, Lee D, et al. Emerging Utility of Virtual Reality as a Multidisciplinary Tool in Clinical Medicine. Games Health J. 2017;6(5):263-270.

44. Chan E, Foster S, Sambell R, et al. Clinical efficacy of virtual reality for acute procedural pain management: A systematic review and meta-analysis. PLoS One. 2018;13(7):e0200987.

45. Harris PA, Taylor R, Minor BL, et al. The REDCap consortium: Building an international community of software platform partners. J Biomed Inform. 2019;95:103208.

46. Harris PA, Taylor R, Thielke R, et al. Research electronic data capture (REDCap)--a metadatadriven methodology and workflow process for providing translational research informatics support. J Biomed Inform. 2009;42(2):377-381.

47. Xiang H, Shen J, Wheeler KK, et al. Efficacy of Smartphone Active and Passive Virtual Reality Distraction vs Standard Care on Burn Pain Among Pediatric Patients- A Randomized Clinical Trial. JAMA Network Open. 2021;4(6):e2112082. 